\title{
Effect of Waste Glass Powder as A Pozzolanic Material in Concrete Production
}

\author{
Agboola Shamsudeen Abdulazeez ${ }^{1}$, Mamman Adamu Idi ${ }^{2}$, Musa Abdulhakeem Kolawole ${ }^{3}$, Bappah Hamza ${ }^{4}$ \\ ${ }^{1,3}$ M.Tech Student, Abubakar Tafawa Balewa University Bauchi, Nigeria \\ ${ }^{2}$ Abubakar Tafawa Balewa University Bauchi, Nigeria \\ ${ }^{4}$ Nigeria Army University, Biu, Borno, Nigeria
}

\begin{abstract}
Over the years, the construction industry consumes large amount of materials. The negative environmental impact and high cost of cement are reasons for research efforts into discovering suitable replacements for cement in concrete production. Cement manufacturing industry is one of the carbon dioxide emitting sources. The global warming is caused by the emission of greenhouse gases to the atmosphere. Among the greenhouse gases, $\mathrm{CO}_{2}$ contributes about $65 \%$ of global warming. The global cement industry contributes about $7 \%$ of greenhouse gas emission to the earth's atmosphere. From observations with regard to the ineffective waste disposal practices in Nigeria, glass waste was analyzed and identified as having potential for use in concrete production. Wastes utilization would not only be economical, but may also help to create a sustainable and pollution free environment. In this paper, chemical test was undertaken on waste glass powder, and has been partially replaced in the ratio of $0 \%, 5 \%, 7.5 \%, 10 \%, 12.5 \% 15 \%$ and $20 \%$ by volume of cement in concrete. Fresh concrete tests like slump and compaction factor test were carried out along with hardened concrete tests which compressive strength, split tensile strength, and flexural strength. The result shows that waste glass powder is a suitable replacement for cement in concrete production. The chemical constituents of the WGP were $\mathrm{SiO} 2$ $(71.30 \%), \mathrm{Al} 2 \mathrm{O3}(2.4 \%), \mathrm{Fe} 2 \mathrm{O3}(0.4 \%), \mathrm{CaO}(8.20 \%), \mathrm{K} 2 \mathrm{O}$ $(0.30 \%), \mathrm{MgO}(0.43 \%), \mathrm{Na}_{2} \mathrm{O}(10.42), \mathrm{Cr}_{2} \mathrm{O}_{3}(0.03), \mathrm{TiO} 2$ $(0.20)$, and $\mathrm{V}_{2} \mathrm{O}_{5}, \mathrm{NiO}, \mathrm{MnO}, \mathrm{S03}$ are not detected. Since $\mathrm{SiO}$, $\mathrm{Al2O3}$, and $\mathrm{Fe} 2 \mathrm{O3}$ have a combined constituent percent in excess of $70 \%$ (i.e. $74.10 \%$ ), WGP meets the requirement of a pozollana in accordance the relevant standards. The WGP concrete gave compressive strength in the range of 21.5 $\mathrm{N} / \mathrm{mm}^{2}$ for $20 \%$ ash and $28.8 \mathrm{~N} / \mathrm{mm}^{2}$ for $10 \%$ ash as compared to $27.8 \mathrm{~N} / \mathrm{mm}^{2}$ for $0 \%$ replacement at 28 days curing period. The result shows that $10 \%$ WGP should not be exceeded for a competitive value for compressive strength. The density of WGP-Cement concrete slightly reduced with increase of WGP at above $12.5 \%$ replacement, as $20 \%$ replacement is reduced by $2.76 \%$ as compared to $0 \%$ at 28days curing. Further work on the Water Absorption Capacity, permeability and durability parameters of WGPCement concrete is recommended.
\end{abstract}

Keywords - Chemical properties, physical properties, compressive strength, split tensile strength, flexural strength, waste glass powder.

\section{INTRODUCTION}

The construction industry searches the alternatives to satisfy the increasing need for cement necessary for concrete production. The global cement consumption in the year 2010 was measured at 3,313 million metric tons, which shows that it is the mostly used and significant material in construction (Vignesh, Devi, Manohari \&
Santha, 2014). According to Mohammad (2010) cement is one of the essential ingredients of concrete that both contributes to the construction industries and causes environmental problem. Manufacturing of cement (key ingredient used for the production of concrete) is a major source of greenhouse gas emissions (Imbabi, Carrigan, \& Mckenna, 2012). It is expensive to buy when compared to other concrete materials such as gravel, sand, water etc. The problems of pollution and cost have led to researches on cement alternatives that will fully or partially replace cement in the construction industry (Ogunbode \& Hassan, 2011). Dadu (2011) reported that the global move currently is to reduce the amount of Portland cement contents used in the concrete mixtures with cheaper Supplementary Cementitious Material (SCM)/pozzolans to improve properties of concrete. The use of supplementary cementitious materials (SCMs) to offset a portion of the cement in concrete is a promising method for reducing the environmental impact from the industry. These materials are used to create blended cements which can improve concrete durability, early and long term strength, workability and economy (Detwiler, Bhatty \& Bhattacharja, 1996). The American Society for Testing and Material (ASTM C125-06) defined pozzolan as a siliceous or siliceous and aluminous material, which in itself possesses little or no cementitious value but which will, in finely divided form and in the presence of moisture, chemically react with calcium hydroxide at ordinary temperatures to form compounds possessing cementitious properties. Shetty (2009) classified pozzolans as either natural or artificial pozzolan. Natural pozzolans include; clay and shales, opalinc cherts, diatomaceous earth, volcanic ash, volcanic tuffs and pumicites, Artificial pozzolans include; fly ash, blast furnance slag, silica fume, rice husk ash, metakaoline and surkhi. According to Joergensen (2014) use of pozzolan to replace OPC in concrete lower heat development during hardening and improve durability of the final concrete structures.

While Nigeria is committed to actively reduce greenhouse emissions $\left(\mathrm{CO}_{2}\right.$ emissions), which is the trending issue globally, the construction industries also have been searching ways to reduce it production if the large amount of waste materials generated were used to replace natural materials in the construction industry. Therefore these would result to three benefits: conserving natural resources, disposing of waste materials (which are often unsightly) and freeing up valuable land for other uses (Blewett \& Woodward, 2000). 
Among the high volumes of waste generated, bottle and glass waste have been identified as having potential for reuse in the construction industry. Researches indicated that glass has a chemical composition and phase comparable to traditional SCMs (Ryou, Shah \& KostaGdoutous, 2006; Nassar and Soroushian, 2012). It is abundant, can be of low economic value and is often land filled (Byars, Meyer and Zhu, 2003).

Glass can be manufactured by melting a mixture of silica (silicon oxide), sodium carbonate, dolomite $\left(\mathrm{CaMg}\left(\mathrm{CO}_{3}\right)_{2}\right)$ and limestone $\left(\mathrm{CaCO}_{3}\right)$ at a high temperature, up to $1600^{\circ} \mathrm{C}$. The mixture is then cooled to solidify without crystallization. The non-liquid and non-solid state makes glass to be an amorphous solid material. Special additives are used to give glasses their colors and specific properties (Heldman, 1946). Different forms of glass are produced, depending on the chemical composition and the additives used, such as: vitreous silica, alkali silicates, soda-lime glasses (containers, float, sheet, light bulbs and tempered ovenware), borosilicate glasses (chemical apparatus, pharmaceutical and tungsten sealing), lead glasses (color TV funnel, neon tubing, electronic parts and optical dense flint), barium glasses (color TV panel and optical dense barium crown), and aluminosilicate glasses (combustion tubes, fiberglass and resistor substrates). These glasses are manufactured in three different colors, mostly green, brown and colorless (McLellan \& Shand, 1984). The world total production of glass was about 89.4 million tons in 2007 . EU countries produced about 38.3 million tons in the same year, which represent approximately $30 \%$ of the total world's production, made EU the world's largest glass producer in 2007 . About $83 \%$ of the EU glass production was container glass and flat glass, i.e. soda-lime glass (Schmitz, Kami_nski, Scalet, Maria, \& Soria, 2011). It is expected that the total production of glass will increase due to the increase in industrialization and the improvement in the standard of living, i.e. the waste glass will increase too. As an example, the total EU's glass waste in 2002 was 3 million tons, while the total EU's glass waste in 2008 was 4.1 million tons (EC, 2010).

Studies also focused on use of waste glass as aggregate in concrete production (Rashed, 2014). Studies on the use of glass as aggregate in concrete were not always satisfactory due to the marked strength reduction and simultaneous excessive expansion (Shao, Lefort, Moras and Rodriguez, 2000). This expansion due to the use of glass as aggregate was termed Alkali-Silica Reaction (ASR). Shao, Lefort, Moras and Rodriguez (2000) further opined that less than $75 \mu \mathrm{m}$, this effect of ASR does not occur and mortar durability is guaranteed. However use of good pozzolan functions to mitigate ASR and consume the lime to greatly reduce efflorescence (Rashed, 2014). ASR can be minimized by adding mineral admixtures in the concrete mixture, common mineral admixtures used to reduce ASR are pulverized fuel ash (PFA), silica fume (SF) and metkaolin (MK). A number of studies have shown the suppressing ability of these materials on ASR. A high amount of waste glass as aggregate is known to decrease the concrete unit weight (Christopher cheeseman, 2011; Mageswari \& Vidivelli, 2010). The fact that glass has high silica content has led to laboratory studies on its feasibility and suitability as a raw material in cement manufacture. The use of finely divided glass powder as a cement replacement material has yielded positive results (Malek, Iqbal, \& Ibrahim, 2007).

Xie and Xi (2002) and Chen et al. (2002) studied the use of waste glass as one of the raw materials to produce Portland cement. Due to the similar chemical composition between waste glass and clay the researchers tried to use waste glass as a partial replacement to clay as opined by (Xie and $\mathrm{Xi}$, 2002) or instead of clay (Chen et al., 2002) in the cement raw materials mixture. The reviewed studies showed that waste glass can be used in cement and concrete but the particle size of the glass waste plays a vital role in the ASR destructive reaction and the performance of concrete. The pozollanic properties of glass increased with decreasing its particle sizes under $100 \mathrm{~mm}$, while, all the experimental results showed that increasing the percentage of waste glass aggregate reduces the maintenance of concrete. A full study is needed to find the optimum percentage of waste glass (as aggregate or cement replacement) and particle size which can be used without any effect on the properties of the produced concrete. Also, there is a need to study the possibility of using the waste glass as a raw material in the production of cement.

\subsection{MATERIALS AND METHODS}

All the materials used for laboratory experiment were procured from the immediate environment. The relevant standards were used in the conducting the experiments.

\subsection{Materials}

The materials for this study included, coarse aggregate fine aggregate, Cement, waste glass powder and water. Waste glass powder was sourced from within Bauchi metropolis, Bauchi local government of Bauchi state, Nigeria. It constituted a waste from mostly containers of beverages which become waste due to mishandling of the can or conrtainer or accidental damages from cars and lorries used in transporting them. They are usually piled up in heaps for sale livestock by the locals. The coarse aggregate was obtained from a quarry site within Bauchi metropolis. The fine aggregate was obtained from Bayara River-flow in Bauchi state. The ordinary Portland cement is the brand of Dangote of Grade 42.5 which was procured from vendors within Bauchi metropolis. Samples of bottle fragments collected were washed and dried then crushed. To pulverize the glass into powder, a locally fabricated mill was used. The powder was sieved through a $75 \mu \mathrm{m}$ sieve.

\subsection{Chemical Analysis of WGP:}

The WGP was analyzed to determine its suitability as a pozollana. The chemical analysis was conducted at Sodexmines Nigeria limited Plateau State, Nigeria, using EDXRF method. The machine used to carry out this test was Minipal 4 Energy Dispersive X-Ray Fluorescence. The major oxides, minor oxides and Lost on Ignition (LoI) were measured and recorded.

\subsection{Workability Tests of the wet WGP-Cement Concrete}

The Compacting factor test was conducted in accordance with British Standard BS EN 12 350- 2:2009BS 1881: Part 
103 (1993). Slump test was also conducted using the relevant cone for measurements. The tests were conducted in accordance with British Standards (1983).

\subsection{Compressive Strength Test}

The compressive strength test was conducted in accordance with British Standards (1970). The 1: 2: 4 mix ratios were adopted using a water cement ratio of 0.5 . The ratio was that of OPC (with replacement levels of WGP), fine aggregate and coarse aggregate respectively. The cubes were cast for cement replacement levels at $0 \%, 5 \%, 7.5 \%$, $10 \%, 12.5 \%, 15 \%$ and $20 \%$, and cured for 7 days, 14 days, 21 days and 28 days respectively. For each mix, 3 cubes were crushed to obtain the average strength of the concrete samples. The compressive strength is the ratio of the weight of cube and the cross sectional area.

\subsection{Split Tensile Strength Test}

In the determination of flexural strength of concrete beams, the procedures as in accordance with BS1881-177: was followed. The cylinder were cast for cement replacement levels at $0 \%, 5 \%, 7.5 \%, 10 \%, 12.5 \%, 15 \%$ and $20 \%$, and cured for 7 days, 14 days, 21 days and 28 days respectively. For each mix, 3 cylindrical specimens were crushed to obtain the average strength of the concrete samples. Jig with packing strips and loading pieces were carefully positioned along the top and bottom of the plane of loading if the specimen. The jig was then place on the machine so that the specimen is placed centrally. The upper platen was parallel to the lower platen. The load was applied steadily and without shock such that the stress in increased at a rate within the range of $0.04 \mathrm{MPa} / \mathrm{s}$ to 0.06 $\mathrm{MPa} / \mathrm{s}$, the rate was maintained at $\pm 10 \%$ until failure. The split tensile strength Fct in $\mathrm{N} / \mathrm{mm}^{2}$ was computed using equation 1.

$\mathrm{Fct}=\frac{2 F}{\pi \mathrm{xLxd}} \quad$ where

$\mathrm{F}$ is the maximum load in $(\mathrm{KN})$

$\mathrm{L}$ is the average measured length in ( $\mathrm{mm})$

$\mathrm{d}$ is the average measured diameter in ( $\mathrm{mm}$ )

The spilt tensile strength is measured is expressed to the nearest $0.05 \mathrm{MPa}$.

\subsection{Flexural Strength Test}

In the determination of flexural strength of concrete beams, the procedures as in accordance with BS1881: Part 4 was followed. The beams were cast for cement replacement levels at $0 \%, 5 \%, 7.5 \%, 10 \%, 12.5 \%, 15 \%$ and $20 \%$, and cured for 7 days and 28 days respectively. For each mix, 3 beams were crushed to obtain the average strength of the concrete samples. The compressive strength is the ratio of the weight of cube and the cross sectional area.

\subsection{Density Test}

This was carried out prior to crushing of the concrete specimen. At the end of each curing period, the concrete specimens were weighed using an electric weighing machine balance. Density is calculated as mass of concrete specimen in $(\mathrm{kg})$ divided by volume of concrete cube $\left(\mathrm{m}^{3}\right)$ and expressed in $\mathrm{kg} / \mathrm{m}^{3}$.

\subsection{Chemical Analysis}

\subsection{RESULTS AND DISCUSSION}

The result of the chemical analysis showing the oxide composition of WGP is presented in Table 1 . The total combined content of silica, alumina and ferric oxides was 74.1\%. ASTM C618 (1981) specifies that for a pozollana to be used as a cement blend in concrete it requires a minimum $70 \%$ amount combined of silica, alumina and ferric oxides. Hence WGP from Nigeria is suitable and can be used as a pozollana.

\subsection{Workability}

The result of the Compacting factor test is shown in Table 2. The values increased with the increase in the proportional ratio of WGP content and with highest value at $20 \%$ cement replacement which further confirmed the use of WGP as possessing pozzolanic property. The Compacting factor values can be categorized as very low (0.78), low (0.85), medium (0.92) and high (0.95) in accordance with Building research establishment and specified by Neville and Brooks (2010). The Slump test results are also in Table 2.The slump values increased with increase ratio of WGP except for $5 \%$ replacement which retains same value as that of $0 \%$ mix. All the values fall within the low range of slump $(35 \mathrm{~mm}-75 \mathrm{~mm})$ in accordance with BS 1881 (1981). According to ENV 206 (1992), $0 \%$ and 5\% replacement was in the S1 classification $(10 \mathrm{~mm}-40 \mathrm{~mm})$ while the remaining were in the $\mathrm{S} 2$ classification $(50 \mathrm{~mm}-90 \mathrm{~mm})$.

\subsection{Compressive strength of the cement/waste glass powder Concrete:}

The results of the compressive strength test are shown in Table 4. The compressive strength increased at $7.5 \%$ and $10 \%$ while the strength at $5 \%$ was same with $0 \%$ specimen, also as the percentage replacement is increased beyond $10 \%$ the strength began to decrease. However the $5 \%$ waste glass powder replacement of cement shows no different in the strength index parameter of the concrete specimen. The $10 \%$ ratio replacement shows high strength over the control specimen and other replacement levels, however higher replacement levels beyond $10 \%$ shows decrease in strength index. It is apparent that $10 \%$ replacement level will produce the optimum strength. However the trend of the compressive strength shows that replacing cement with more than $10 \%$ replacement of WGP will give lower strength as compared to the control.

\subsection{Split tensile strength of the cement/waste glass powder Concrete:}

The results of the tensile strength test are shown in Table 6 . The tensile strength increased at 5\%, $7.5 \%$ and $10 \%$ while the strength starts to decrease beyond $10 \%$ replacement levels. The $5 \%, 7.5 \%$ and $10 \%$ replacement ratios shows high strength over the control specimen, while other replacement levels above $10 \%$ shows decrease in strength index.

\subsection{Flexural strength of the cement/waste glass powder Concrete:}

The results of the compressive strength test are shown in Table 8 . The flexural strength was tested at 7 and 28 days only. At 7 days the strength of the beams at 5\% $7.5 \%$ and $10 \%$ increased beyond the control, while at 28 days $7.5 \%$ and $10 \%$ increased beyond the control at $0 \%$. However the $5 \%$ waste glass powder replacement of cement was slightly less than the control specimen. The $12.5 \%, 15 \%$ and $20 \%$ 
shows decreased in strength as compared to the control sampleIt is apparent that $10 \%$ replacement level will produce the optimum strength.

\subsection{Density of the WGP-cement Concrete:}

The results of the density test are shown in Table 3. The densities of concrete cubes at 5\% 10\% and $12.5 \%$ shows higher densities at 28 days period of curing as compared to the control concrete specimen, while the density of $15 \%$ and $20 \%$ show decreased in density of the cubes specimen as compared to the control.

\subsection{CONCLUSION}

Waste glass powder was cleaned, then grinded and sieved. The oxide composition of the powder showed that it can possess and can be used as a pozzolanic material with essential constituent of a pozollana which include $71.3 \%$ $\mathrm{SiO}_{2} 2.4 \% \mathrm{Al}_{2} \mathrm{O}_{3}$ and $0.4 \% \mathrm{Fe}_{2} \mathrm{O}_{3}$ content summing up-to to $74.1 \%$ as presented in table 4 . The WGP was used to replace cement at $5 \%-20 \%$ in ratios. The workability of the fresh mixes fell within the low and medium classifications. The Compressive strengths declined at above $10 \%$ replacement level of cement at 28 days curing which indicates that $10 \%$ and $15 \%$ replacement levels meet the requirement of BS EN 206-1: 2000 for class C25/30 and C20/25 respectively for heavy weight concreting and LC25/28 and LC20/22 respectively for light weight concreting. In conclusion, while the tensile strength decreased above $12.5 \%$ while the flexural strength decreased at above $12.5 \%$ replacement levels, with $10 \%$ replacement level with the highest strength index. The study suggests that WGP could be replaced up-to $15 \%$ with $10 \%$ replacement level with best $\mathrm{mx}$ using W/C ratio of 0.5 . The density related values shows similar result with reduced density at 28 days. The research concluded that the WGP is a good pozzolanic material for concrete and at $10 \%$ optimum replacement levels can produce very strong concrete but can be used up-to $15 \%$. Further study are recommended on other properties such as setting times, water absorption capacity, permeability, durability on concrete and mortars made with WGP replacements, Admixtures may be added to improve performance, also using a different mix and altering water cement ratio is also recommended.

Table 1: Energy Dispersive X-Ray Fluorescence (EDXRF) Method of Waste Glass Powder in Comparison with Pereira et al. (2004) and ASTM Requirement.

\begin{tabular}{|c|c|c|c|c|}
\hline Elements & \% Composition & \% Composition & \multicolumn{2}{|l|}{ ASTM C618-05 } \\
\hline Aluminum Oxide $\left(\mathrm{Al}_{2} \mathrm{O}_{3}\right)$ & 2.40 & & 2.54 & $\mathrm{Al}_{2} \mathrm{O}_{3}$ \\
\hline Silicon Oxide $\left(\mathrm{SiO}_{2}\right)$ & 71.30 & & 72.25 & + \\
\hline Iron Oxide $\left(\mathrm{Fe}_{2} \mathrm{O}_{3}\right)$ & 0.40 & & ---- & $\mathrm{SiO}_{2}$ \\
\hline Potassium Oxide $\left(\mathrm{K}_{2} \mathrm{O}\right)$ & 0.30 & & 1.15 & + \\
\hline Calcium Oxide $(\mathrm{CaO})$ & 8.20 & & 12.35 & $\mathrm{Fe}_{2} \mathrm{O}_{3}$ \\
\hline Titanium Oxide $\left(\mathrm{TiO}_{2}\right)$ & 0.20 & & ---- & $=$ \\
\hline Vanadium Oxide $\left(\mathrm{V}_{2} \mathrm{O}_{5}\right)$ & N.D & & ---- & $70.00 \%$ \\
\hline Chromium Oxide $\left(\mathrm{Cr}_{2} \mathrm{O}_{3}\right)$ & 0.02 & & ---- & \\
\hline Manganese Oxide (MnO) & N.D & & ---- & \\
\hline Magnesium Oxide (MgO) & 0.43 & & 1.18 & \\
\hline Nickel Oxide (NiO) & N.D & & ---- & \\
\hline Sodium Oxide $\left(\mathrm{Na}_{2} \mathrm{O}\right)$ & 10.42 & & 10.54 & \\
\hline Sulphur trioxide $\left(\mathrm{SO}_{3}\right)$ & N.D & & ---- & \\
\hline Loss on Ignition (LOI) & & ---- & ---- & \\
\hline
\end{tabular}

Table 2: Slump and Compacting factor

\begin{tabular}{|c|c|c|c|}
\hline WGP content & $\mathrm{W} / \mathrm{C}$ ratio & Slump $(\mathrm{mm})$ & Compacting factor \\
\hline $0 \%$ & 0.5 & 30 & 0.85 \\
\hline $5 \%$ & 0.5 & 30 & 0.87 \\
\hline $7.5 \%$ & 0.5 & 35 & 0.88 \\
\hline $10 \%$ & 0.5 & 35 & 0.88 \\
\hline $12.5 \%$ & 0.5 & 45 & 0.89 \\
\hline $15 \%$ & 0.5 & 50 & 0.89 \\
\hline $20 \%$ & 0.5 & 55 & 0.92 \\
\hline
\end{tabular}

Table 3: Density of samples

\begin{tabular}{lllll}
\hline WGP content & 7days & 14days & 21 days & 28 days \\
\hline $0 \%$ & 2510 & 2500 & 2490 & 2530 \\
$5 \%$ & 2540 & 2520 & 2510 & 2555 \\
$7.5 \%$ & 2480 & 2550 & 2540 & 2490 \\
$10 \%$ & 2510 & 2460 & 2585 & 2530 \\
$12.5 \%$ & 2525 & 2515 & 2540 & 2550 \\
$15 \%$ & 2490 & 2533 & 2365 & 2455 \\
$20 \%$ & 2466 & 2455 & 2480 & 2460 \\
\hline
\end{tabular}


Table 4: Compressive strength of WGP samples

\begin{tabular}{lllll}
\hline WGP content & 7 days & 14 days & 21 days & 28 days \\
\hline $0 \%$ & 17.9 & 21.6 & 24.9 & 27.8 \\
$5 \%$ & 17.8 & 21.9 & 25.1 & 27.8 \\
$7.5 \%$ & 17.8 & 21.6 & 25.7 & 28.0 \\
$10 \%$ & 18.3 & 22.4 & 25.9 & 28.8 \\
$12.5 \%$ & 17.2 & 21.5 & 25.0 & 27.5 \\
$15 \%$ & 15.6 & 19.8 & 23.1 & 24.5 \\
$20 \%$ & 14.2 & 16.1 & 18.9 & 21.5 \\
\hline
\end{tabular}

Table 5: Density of samples

\begin{tabular}{lllll}
\hline WGP content & 7 days & 14days & 21 days & 28 days \\
\hline $0 \%$ & 2610 & 2655 & 2649 & 2726 \\
$5 \%$ & 2590 & 2620 & 2575 & 2645 \\
$7.5 \%$ & 2678 & 2742 & 2633 & 2595 \\
$10 \%$ & 2502 & 2460 & 2585 & 2665 \\
$12.5 \%$ & 2538 & 2525 & 2570 & 2517 \\
$15 \%$ & 2605 & 2560 & 2555 & 2582 \\
$20 \%$ & 2395 & 2420 & 2475 & 2500 \\
\hline
\end{tabular}

Table 6: Split tensile strength of WGP samples

\begin{tabular}{lllll}
\hline WGP content & 7days & 14days & & 21days \\
\hline $0 \%$ & 2.53 & 2.79 & 3.11 & 3.38 \\
$5 \%$ & 2.58 & 2.79 & 3.21 & 3.40 \\
$7.5 \%$ & 2.65 & 2.78 & 3.10 & 3.41 \\
$10 \%$ & 2.68 & 2.84 & 3.29 & 3.46 \\
$12.5 \%$ & 1.95 & 2.50 & 2.60 & 2.75 \\
$15 \%$ & 1.88 & 1.93 & 2.35 & 2.55 \\
$20 \%$ & 1.58 & 1.66 & 2.01 & 2.18 \\
\hline
\end{tabular}

Table 7: Density of WGP beam samples

\begin{tabular}{lll}
\hline WGP content & 7 days & 28 days \\
\hline $0 \%$ & 2460 & 2500 \\
$5 \%$ & 2480 & 2490 \\
$7.5 \%$ & 2455 & 2470 \\
$10 \%$ & 2510 & 2510 \\
$12.5 \%$ & 2500 & 2500 \\
$15 \%$ & 2480 & 2490 \\
$20 \%$ & 2380 & 2445 \\
\hline
\end{tabular}

Table 8: Flexural strength of WGP-cement concrete samples

\begin{tabular}{lll}
\hline WGP content & 7 days & 28 days \\
\hline $0 \%$ & 4.37 & 4.70 \\
$5 \%$ & 4.41 & 4.68 \\
$7.5 \%$ & 4.41 & 4.71 \\
$10 \%$ & 4.47 & 4.77 \\
$12.5 \%$ & 4.33 & 4.65 \\
$15 \%$ & 4.27 & 4.48 \\
$20 \%$ & 4.17 & 4.28 \\
\hline
\end{tabular}

\section{REFERENCE}

[1] Vignesh K.N., Devi S.A., Manohari S.P, and Santha M.M. (2014). Experimental Study on partial replacement of cement with coconut shell ash in concrete. International Journal of Science and Research (IJSR), Volume 3, issue 3.

[2] Muhammed, N. F., (2010). Performance of Concrete by Using Pulverized Fuel Ash (PFA) as Cement Replacement Material. Unpublished B.Sc. Project, Department of Civil Engineering and Earth Resources, University of Malaysia, Pahang.

[3] Imbabi. S.M., Carrigan. C. and Mckenna S. (2012). "Treand and Developments in Grean Cement and Concrete Technology", International Journal of Sustainable Built Environment.1(2), 194-216.

[4] Ogunbode, E. B. and Hassan, I. O. (2011). Effect of Addition of Calcium Nitrate on Selected Properties of Concrete Containing Volcanic Ash. Leonardo Electronic Journal of Practice and Technologies, 29-38. Retrieved Date: January 16, 2019, from http://www.lejpt.academicdirect.org
[5] Dadu, D. W. (2011). Investigation into Pozzolanic Characteristics of Jos Plateau Volcanic Deposits for Partial Replacement of Portland Cement in Concrete. Unpublished Ph.D Dissertation Work. Department of Building Faculty of Environmental Design, Ahmadu Bello University Zaria, Nigeria.

[6] Detwiler R.J., Bhatty J.I., Bhattacharja S. (1996) Supplementary Cementing Materials for Use in Blended Cements. Research and Development Bulletin Rd112, Portland Cement Association.

[7] American Society for Testing and Material. (2006). Standard Terminology Relating to Concrete and Concrete Aggregates. American Society for Testing and Material, West Conshohocken, No C125. USA.

[8] Shetty M. S. (2009). Concrete Technology; Theory and Practice, S. Chand and Company, New Delhi, India, 174-418.

[9] Joergensen, S. W. (2014). Grinding of Clinker Replacement Materials. Special Report by General Manager Grinding Technology, 1-15. 
[10] Blewett, J. and Woodward, P. K. (2000). Some Geotechnical Properties of Waste Glass, Department of civil and offshore engineering, Heriot-Watt University, Edinburgh.

[11] Ryou, J., Shah, S.P., and Konsta-Gdoutos, M.S. (2006). Recycling of cement industry wastes by grinding process. Adv. Appl. Ceram. 105, 274-279.

[12] Byars, E., Meyer, C., Zhu, H.Y. (2003). Use of waste glass for construction products: legislative and technical issues. In: Dhir, R.K., Newlands,M. D., Halliday, J.E. (Eds.), Recycling and Reuse of Waste Materials. Thomas Telford Ltd., London, United Kingdom, pp. 827-838.

[13] Heldman, J.D. (1946) Techniques of Glass Manipulation in Scientific Research, Prentice Hall, New York.

[14] McLellan, G.W and Shand, E.B. (1984). Glass Engineering Handbook, McGraw-Hill,USA.

[15] Schmitz, A., Kaminski, J., Scalet B.M. and Soria, A. (2011) Energy consumption and $\mathrm{CO}_{2}$ emissions of the European glass industry, Energy Policy 39 (2011) 142-155, http://dx.doi.org/10.1016/j.enpol.2010.09.022.

[16] European Commission, Environmental Statistics and Accounts in Europe, Eurostat Statistical Books, 2010.

[17] Rashed, A.M. (2014). Recycled waste glass as fine aggregate replacement in cementitious materials based on Portland cement. Constr. Build. Mater. 72, 340-357.

[18] Shao, Y., Lefort., Moras. and Rodriguez, Z. (2000). Studies on Concrete Containing Ground Waste Glass. Cement and Concrete Research 30: 91-100.

[19] Christopher cheeseman, (2011). " Production of sintered light weight aggregate using waste ash and other industrial residues", Belgium, 2011.

[20] Malek Batayneh, Iqbal Marie and Ibrahim Asi,(2007). "Use of Selected waste Materials in Concrete Mixes", Waste Management, vol. 27.

[21] Xie, Z. and Xi, Y. (2002). Use of recycled glass as a raw material in the manufacture of Portland cement, Materials and Structures $\quad 35, \quad 510-515, \quad$ http://dx.doi. org/10.1007/BF02483139.

[22] Chen, G., Lee, H., Young, K.L., Yue, P.L., Wong, A., Tao, T., Choi, K.K., (2002). Glass recycling in cement production-an innovative approach, Waste Management (New York, N.Y.) 22, 747-753, http://dx.doi.org/10.1016/S0956-053X(02)000478. 12365777 .

[23] British Standards, BS 1881 Part 102, Method of Determination of Workability (London: British Standard Institution, 1983).

[24] British Standards, BS 1881 Part 4, Method of Testing Concrete for Strength (London: British Standard Institution BSI, 1970).

[25] American Society for Testing Materials, C618, Specification for Fly Ash and Raw or Calcined Natural Pozollana for use as mineral/admixture in Portland cement concrete (Washington: ASTM, 1981)

[26] Neville, A. M. and Brooks J. J. (2010). Concrete Technology; 2nd Edition, Longman Group, United Kingdom, 30-269.

[27] British Standards, BS 1881: Part 103, Method for Determination of Compacting Factor (London: British Standard Institution, 1993)

[28] European Standards ENV 206: 1992. Concrete: Performance, Production, Placing, and Compliance Criteria (Brussels: European Standards ENV, 1992) 